\title{
An origin story: ribozyme catalysis by the ribosome
}

\author{
JANE E. JACKMAN \\ Department of Chemistry and Biochemistry, The Ohio State University, Columbus, Ohio 43210, USA
}

The answer to the question "What does your lab do?" from non-scientist friends, strangers, or family members often requires some explanation. For me (as with many in the RNA field), the answer to this question typically requires an immediate simplification, often starting with "Well, you have heard of DNA? We study RNA, which is similar...”. Contemporary science outreach and education seems to have successfully made the larger non-scientific world generally aware of the critical roles for DNA in the fascinating biology that we all know of as life. Yet it often remains necessary to explain that there is "another" nucleic acid that plays equal, and for many of us, arguably even more important, roles in the function of living things. In the same way, a journal that focuses explicitly on RNA fulfills this critical function even among scientists. For 20 years, the RNA journal has provided the RNA community with a valuable forum for disseminating high-quality research findings on all aspects of RNA structure, function, and biology, and in doing so it has raised the profile of RNA-related research among the entire scientific community. Indeed this is something to be celebrated.

As a relative newcomer to the RNA world, having only begun my work on RNA as a post-doc some 15 years ago, I realize that in some ways I have taken knowledge of and interest in RNA for granted. As a graduate student, I heard stories of the initial skepticism regarding RNA-based catalysts and extraordinary efforts by many RNA pioneers to convince the scientific community of the reality of RNA enzymes. Nonetheless, by the time I was in graduate school, the Nobel Prize awarded to Sidney Altman and Tom Cech was nearly a decade old and ribozymes were more or less an accepted biological phenomenon. When I think about the discoveries that most sparked my own interest in and passion for RNA, the discovery of RNA catalysis remains a source of fascination for me to this day. Given my own background and training as an enzymologist, perhaps this predictably reflects my love for understanding the chemical basis for the reactions that enable life. Yet, the idea that RNA enzymes catalyze numerous reactions in biology is exciting for reasons beyond simply understanding the minutiae of chemical catalysis. Indeed, I believe one of the reasons that the very idea of

Corresponding author: Jackman.14@osu.edu

Article and publication date are at http://www.rnajournal.org/cgi/doi/ $10.1261 /$ rna.050328.115. Freely available online through the RNA Open Access option. ribozymes connects so viscerally with many scientists is because of the natural awe inspired by beholding things that are connected to history, akin to viewing an ancient artifact from an earlier culture. Therefore, when given the difficult task of choosing what I think is the most significant discovery during the past 20 years of RNA-related research, I reach back to my fascination with ribozyme catalysis. Although an abundance of exciting and paradigm-altering observations in the field of RNA makes this a daunting task, the discovery and structural characterization of an ancient ribozyme in the form of the ribosome is an observation that had a significant impact on diverse fields from chemistry to biology, and continues to provoke new questions today.

I realize that, at least in part, my own interest in the impact of ribozyme catalysis by the ribosome is inextricably connected to my attendance at my first RNA meeting in 2000 in Madison, Wisconsin. There, I had my first experience with the vibrant community that makes up the RNA field. As a new post-doc, I attended this meeting with anticipation, excited to learn about the newest techniques and ideas from leaders in my recently chosen field. Little did I know that the very first session on Tuesday night would include talks about the structure and function of the ribosome, many of which included results that would serve as the foundation for the future Nobel Prize awarded for the elucidation of ribosome structure and function in 2009. Late at night, and admittedly tired after a long day, I remember sitting in the upper balcony listening to multiple talks in quick succession from the Steitz, Yonath, Agrawal, Noller and Williamson labs and realizing even then at my early stage that I was witnessing something important. I was entirely struck by the concept of a ribozyme on such a massive scale and with such a central role in all biological systems; the excitement that emanated from these talks was obvious even to someone new to the field.

As the initial structures and biochemical characterization of the ribosome gave way to more sophisticated analyses of the mechanism of ribosome catalysis, the techniques that erupted to enable mechanistic studies with relatively small ribozymes were rapidly applied to this much larger and very challenging system. Tools for synthesizing and manipulating defined RNA molecules became more sophisticated and

(C) 2015 Jackman This article, published in $R N A$, is available under a Creative Commons License (Attribution-NonCommercial 4.0 International), as described at http://creativecommons.org/licenses/by-nc/4.0/. 
alterations to individual bases and even atomic-level mutagenesis allowed the mechanistic characterization of catalysis. Sophisticated and painstaking kinetic and biophysical approaches provided a framework for studying individual steps of the enzyme reaction. Since the first ribosome structures were obtained, it has been exciting to see the initial hypotheses of acid-base catalysis by a conserved adenosine yield to the current understanding of the role of the substrate itself (in the form of the tRNA $2^{\prime}-\mathrm{OH}$ ) in the chemistry of peptidyl-transfer and the significant role of the ribosome as an entropy trap to lower entropic barriers to peptide bond formation. These discoveries have sparked important biological questions, from understanding the mechanisms of antibiotics that target the ribosome-many of which remain critical tools for the field of medicine- - to understanding how protein synthesis is regulated and controlled. Again, the coincidental development of tools for massively parallel RNA sequencing enabled sophisticated studies of ribosome function in the form of ribosome profiling. Along the way, the computational, biochemical, genetic and chemical approaches to understanding ribosome catalysis have sparked many fundamental insights into the world around us.

Deciphering so many aspects of the mechanism of such a complicated macromolecular machine as the ribosome has been an amazing technical feat. The numerous valuable contributions to biology and chemistry that resulted from this work, far too many to be described here, clearly make this a worthy candidate for one of the most significant discoveries in the RNA field over the past 20 years. And yet, for me these discoveries are important on an even higher level, because they connect our distant scientific past to the promise of our future. Although the small ribozymes that were the first discovered members of this important group are clearly significant in many biological systems, the observation of a fundamentally conserved RNA-catalyzed pathway for something as central to biology as protein synthesis provides a strong rationale for the existence of an earlier RNA world. Even in the undergraduate classes I currently teach, although the concept of ribozyme catalysis by introns and viruses is always a popular topic, catalysis by the ribosome captures students' imaginations in a way that very few other topics can. Now, as our world faces many challenges that raise questions about the sustainability of life itself, solutions may be found in the use of ribosomes as part of the synthetic biology toolkit. Only with the fundamental knowledge of the ribosome's mechanism well in hand can we start to think about how to reengineer this machine to provide biologically and pharmacologically important molecules that have the potential to significantly impact human health and our environment. Thus, despite the fact that protein enzymes (albeit that act on RNA substrates) are the focus of my own research and have provided me and my lab with many exciting questions to answer, the ribosome and its connections to our biological past, present, and future remain an endless source of fascination and wonder for me and I celebrate these connections, along with the RNA journal's role in these discoveries. 

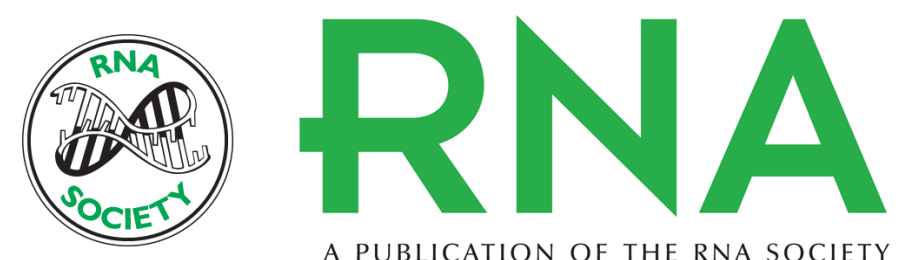

A PUBLICATION OF THE RNA SOCIETY

\section{An origin story: ribozyme catalysis by the ribosome}

Jane E. Jackman

RNA 2015 21: 650-651

Open Access Freely available online through the RNA Open Access option.

Creative This article, published in RNA, is available under a Creative Commons License Commons (Attribution-NonCommercial 4.0 International), as described at

License http://creativecommons.org/licenses/by-nc/4.0/.

Email Alerting Receive free email alerts when new articles cite this article - sign up in the box at the Service top right corner of the article or click here. 